\title{
Uma visita a Georg Simmel: o "conflito" como uma categoria crítica de análise conceitual fundamental para os estudos antropológicos de violências no Brasil ${ }^{*}$
}

\author{
Micheline Ramos de Oliveira ${ }^{1}$ \\ Faculdade Estácio de Sá
}

\begin{abstract}
Nesse artigo faço um debate acerca de juízos estéticos e reflexivos presentes nas escolhas metodológicas dos antropólogos nos estudos de violências no Brasil, elegendo o "conflito simmeliano" como uma categoria crítica de análise conceitual fundamental no indicativo da necessidade de um constante escrutínio dos valores incrustados em nossos pressupostos teóricos, cujos argumentos parecem, nos estudos antropológicos das violências, por vezes, não escaparem da conhecida ideologia liberal iluminista e normatizadora, constituinte, entre outros, de nosso discurso de política e poder na contemporaneidade.
\end{abstract}

Palavras-chave: Conflito simmeliano Antropologia das violências.
In these article I make a debate concerning the reflexive and aesthetics judgments which are present in anthropologist methodological choices, specifically on Brazilian "violence studies", electing the "Simmelian conflict" as a fundamental critical category of conceptual analysis that indicates a constant urge to scrutinizing the incrusted values in our theoretical assumptions, whose arguments, in case of "anthropological violences studies", sometimes, seems not to escape of the well-known normative and illuminist liberal ideology, constituent of, among others, power and politics discourse in contemporanity.

Keywords: Simmelian conflict - Anthropology of violence.

\footnotetext{
A e eleger fazer nesse artigo um debate "em torno da conjunção de juízos estéticos e reflexivos" nas escolhas metodológicas dos antropólogos nos estudos de violências no Brasil, penso no "conflito simmeliano"2 como uma

"A visit to Georg Simmel: the "conflict" as a critical category for conceptual analysis in the studies on violence in Brazil

${ }^{1}$ Doutora em Antropologia Social pela Universidade Federal de Santa Catarina. Docente da Faculdade Estácio de Sá de Santa Catarina. Endereço para correspondências: Faculdade Estácio de Sá de Santa Catarina, Av. Leoberto Leal, 431, Barreiros, São José, SC, 88117-001 (micheantr@hotmail.com). ${ }^{2}$ Para Simmel (1984; p. 122-23)
}

[...] Se toda interação entre os homens é uma sociação, o conflito - afinal, uma das mais vívidas interações e que, além disso, não pode ser exercida por um indivíduo apenas deve certamente ser considerado uma sociação [...] O conflito está assim destinado a resolver dualismos divergentes; é um modo de conseguir algum tipo de unidade, ainda que através da aniquilação de uma das partes conflitantes [...] O conflito contém algo de positivo. Todavia, seus aspectos positivos e negativos estão integrados; podem ser separados conceitualmente, mas não empiricamente. 
categoria crítica de análise conceitual fundamental no indicativo da necessidade de um constante escrutínio dos valores incrustados em nossos pressupostos teóricos, cujos argumentos parecem, por vezes, não escaparem da conhecida ideologia liberal iluminista e normatizadora constituinte, entre outros, de nosso discurso de política e poder ${ }^{3}$ na contemporaneidade.

Minha aproximação com as idéias de conflito defendidas por Simmel começou em meu mestrado realizado entre os anos de 2000-2002 no PPGAS / UFSC, quando pesquisei trajetórias sociais e itinerários urbanos de mulheres/ mães moradoras de uma favela denominada Matadouro, situada no município de Itajaí/SC. Foi, a partir do uso de métodos já clássicos na antropologia, como a descrição densa (GEERTZ, 1978) daquele contexto, alcançada prioritariamente pela observação participante (MALINOWSKI, 1976), pela etnografia do cotidiano (De CERTEAU, 1995) e ainda pelo estudo de narrativas biográficas (ECKERT \& ROCHA, 2000), que in loco comecei a refletir sobre uma certa "inadequação" de alguns pressupostos teóricos e metodológicos que gravitam em torno da temática das violências, no sentido de irem na contramão daquela realidade estudada, que bem ao "gosto" simmeliano exibia que dentro da "sociação" cabe um elemento de conflito. Nesse sentido seleciono um trecho do meu diário escrito nos idos de 2000 durante o meu campo de mestrado:

Hoje, 9 de maio de 2000, estou mais uma vez no "boteco" da Dna. Maria, neste momento não estou mais apenas em frente a uma "velha conhecida", dirigente da Associação de Moradores do bairro [...] Aquela mulher que está sempre pronta para resolver um "pepino" do bairro, ou é cumprimentada por todos a sua volta [...] Estou diante de uma moradora do bairro Matadouro, que vive numa área do local denominada pejorativamente pela vizinhança de "a negada lá de baixo"[...] Uma mulher que em seu "pedaço" vive imersa numa "província de significados", em que o conflito parece constituir e atravessar sejam suas relações com os seus vizinhos evangélicos, traficantes, vizinhança em geral, entre outros. Vejamos algumas palavras de Dna Maria: "Esses evangélicos, esses crentes são um porre minha filha [...] de vez em quando saem corridos daqui de casa,

\footnotetext{
${ }^{3}$ Em seu texto intitulado "Encarando o poder: velhos insights, novas questões" (WOLF, 2003; p. 340) chama-nos atenção de forma crítica para o esquecimento da problematização do poder na história da Antropologia, nesse sentido o autor faz uma apologia, eis suas palavras: "a uma antropologia que não se contenta meramente em traduzir, interpretar ou jogar com um caleidoscópio de fragmentos culturais, mas que busca explicações para os fenômenos culturais[...]Entendo a antropologia como um empreendimento cumulativo, bem como uma busca coletiva que avança em círculos em expansão, uma busca que depende das contribuições de cada um de nós e pelas quais somos todos responsáveis".
} 
Uma visita a Georg Simmel: o "conflito" como uma categoria crítica de análise conceitual ... Micheline Ramos de Oliveira

principalmente quando vem me incomodar no Domingo, quando eu tô de bom humor, até mando eles entrar, ofereço um cafezinho pra eles, e assim vai, entre tapas e beijos a gente vai vivendo [...]". "Esses traficantes só fazem denegrir ainda mais a imagem do bairro, quando eu perco a paciência vou em cima deles mesmo, mas de vez em quando eles dão um brinquedinho pra rapaziada, quebram algum galho pra gente, daí assim vai indo [...]". "Essa gente porca vive jogando lixo na minha porta, depois ainda reclamam quando a gente xinga, um dia desses quase me peguei nos tapas com aquela vizinha ali da frente, fazer o que não é? Vizinho a gente não escolhe [...]"

Então, se num primeiro momento fiz uso dos já clássicos métodos antropológicos com o intuito de investigar, utilizando uma expressão de Geertz "o ponto de vista dos nativos" sobre violências, quando ingressei em 2005 no doutoramento, o meu objetivo era a partir de minha experiência de mestrado e de um alargamento e de uma densificação de minha etnografia continuar refletindo sobre a problemática das violências, agora discutindo além dos dados etnográficos, uma etnografia da etnografia, ou seja, investigando uma suposta violência que possa estar impregnada a um certo tipo de pensamento antropológico que ao negar o conflito corre o risco de se tornar hegemônico e universalizante.

Ora, pode parecer paradoxal numa discussão preocupada com a produção de discurso de política e poder eleger um autor que prima pelos estudos da forma como crucial para sua análise, isso se não estivéssemos atentos a idéia de que para Simmel a forma do procedimento pode valer tanto ou mais que o conteúdo que se chega, simplesmente porque o conteúdo só é de determinado modo enquanto resultado de um determinado tipo de procedimento.

Nesse sentido, Simmel nos dá uma ferramenta importante para pensarmos e refletirmos sobre o processo de nossas pesquisas a medida que demonstra o sentido e validade da ênfase na forma e no procedimento diante da constatação de que o processo afeta os resultados. Isso quer dizer que o conteúdo só terá sentido enquanto relacionado a uma forma (WAIZBORT, 2000).

Poderíamos pensar então que o aspecto formal do procedimento coordena, determina o processo de investigação, assim, dando ênfase aos processos, temos a possibilidade de ver como, por de trás de um conteúdo fixado há um processo que conduziu a ele (WAIZBORT, 2000). Se esse processo se dará de uma forma ou de outra dependendo por exemplo de nossas escolhas teóricometodológicas, das suas formas de lidar e proceder com o objeto, Simmel brinda-nos com a possibilidade da mobilidade perante esse processo, eis o desafio: pensarmos nossos estudos de violências não mais pautados por uma tradição, 
embora camuflada, ainda inspirada por uma sociologia durkheimiana do consenso e das sociologias marxistas e weberianas do conflito ${ }^{4}$.

Todos sabemos o quão paradoxal pode ser, como bem nos alertou Foucault $^{5}$, um discurso ${ }^{6}$ aparentemente neutro para a legitimação de práticas sociais encobridoras de relações de poder. O antropólogo passa aqui, do papel de mero observador e toma o lugar de sujeito posicionado, auto - crítico de suas adesões teórico - políticas, capaz de enxergar sua participação direta ou indireta na construção e desconstrução dos discursos vigentes.

Aqui um dos recursos metodológicos fundantes da antropologia- o distanciamento necessário do objeto de análise para uma produção de saber no mínimo coerente, não deságua num relativismo radical, pelo contrário, utiliza esse distanciamento para repensar, critérios para distinguir uma postura política progressista de uma política conservadora, não servindo mais de desculpa para uma aparente postura a-política e a-crítica, postura essa incoerente desde quando reconhecemos o antropólogo como autor.

${ }^{4}$ Aqui permitam-me uma digressão: Se existe a possibilidade de ruptura, do modo como estudamos as violências no Brasil, porque insistimos em pressupostos teóricos, nesse caso, muitas vezes pautados por uma teoria do consenso, que nega o conflito, ou por uma teoria que o abomina, ao invés de vê-lo como constituinte de um processo de interação? Aqui, recorro a (DELEUZE \& GUATTARI, 2004; p. 18) quando esses discorrem sobre o "princípio de ruptura" do rizoma. Para os autores, "[...] um rizoma pode ser rompido, quebrado em um lugar qualquer, e também retoma segundo uma ou outra de suas linhas e segundo outras linhas[...] Todo rizoma compreende linhas de segmentaridade segundo as quais ele é estratificado, territorializado, organizado, significado, atribuído, etc.; mas compreende também linhas de desterritorialização pelas quais ele foge sem parar. Há ruptura no rizoma cada vez que linhas segmentares explodem numa linha de fuga, mas a linha de fuga faz parte do rizoma. Estas linhas não param de se remeter uma às outras. È por isto que não se pode contar com um dualismo ou uma dicotomia, nem mesmo sob a forma rudimentar do bom e do mau. Faz-se uma ruptura, traça-se uma linha de fuga, mas corre-se sempre o risco de reencontrar nela organizações que reestratificam o conjunto, formações que dão novamente o poder a um significante, atribuições que reconstituem um sujeito - tudo o que se quiser, desde as ressurgências edipianas até as concreções fascistas. Os grupos e os indivíduos contêm microfascismo sempre à espera de cristalização[...] $\mathrm{O}$ bom e o mal são somente o produto de uma seleção ativa e temporária a ser recomeçada[...]”.

${ }^{5}$ Ver Foucault (1972a e 1972b).

${ }^{6}$ Segundo Joan Scott (1999; 205-07), Michel Foucault nos fala que "[...] um discurso não é uma linguagem nem um texto, mas uma estrutura histórica, social e institucionalmente específica, de enunciados, termos, categorias e crenças. Foucault sugere que a elaboração de significado implica conflito e poder, que os significados são questionados localmente dentro de 'campos de força' discursivos, que (ao menos desde o iluminismo) o poder para controlar determinado campo reside em alegações referidas a um saber (científico) incrustado não somente em escritos[...] Portanto, o discurso se encontra ou se expressa tanto nas organizações e instituições como em palavras; tudo isto constitui textos ou documentos para serem lidos. Os terrenos discursivos se sobrepõem, se influenciam, e competem entre si; fazem apelos a suas respectivas "verdades" em busca de autoridade e legitimação[...] O poder dessas "verdades" provém da forma em que funcionam como fatos ou premissas básicas para ambos os lados, em um debate, de tal maneira que o que se realiza é um conflito entre os terrenos discursivos e não um questionamento dessas verdades. Muito do brilho do trabalho de Foucault está em ter chamado a atenção para as pressuposições compartilhadas daqueles que pareciam ser argumentos agudamente diferentes, expondo assim os limites da crítica radical e o alcance do poder das ideologias ou epistemologias dominantes. Foucault emite um aviso contra as soluções simples para os problemas difíceis, e aconselha aos atores humanos pensar de maneira mais estratégica e mais autoconsciente sobre as implicações filosóficas e políticas que nos respaldam[...]" 
Nesse mesmo viés, penso de acordo com (MOOR, 2000), que dentro da academia além de lugar teórico, há um lugar político, aliás, que o próprio lugar teórico revela lugar político, questionando as categorias unitárias e universais e tornando histórico e contextual conceitos que normalmente são tomados como naturais.

Nesse ínterim, o texto clássico de Zaluar (1999) pode ser considerado emblemático, já que longe de ser apenas uma periodização histórica das produções intelectuais sobre o tema, o livro é antes uma tentativa de organizar o vasto e diversificado debate, a partir da relação paradoxal entre a postura do cientista social (orgânico ou universal) e os modelos explicativos acionados, definidos como modelo marxista dicotômico de sociedade, modelo da construção da nação, modelo da organização da sociedade civil, modelo da sociabilidade violenta.

O que podemos perceber é que existe aí nesses modelos, fora o último, a presença menos ou mais explícita de pressupostos teóricos e metodológicos investidos de uma inspiração durkheimiana do consenso e das sociologias marxistas e weberianas do conflito.

É importante ressaltar que o recente livro de (MISSE, 2006), intitulado "Crime e violência no Brasil contemporâneo - estudos de Sociologia do crime e da violência urbana", pode corroborar com a discussão suscitada pelo levantamento elaborado por (ZALUAR, 1999), pois embora tenha sido escrito quase uma década depois de "Violência e crime", o autor atualiza em sua coletânea uma lista de trabalhos e discussões que encontram em seu cerne a problemática de pesquisas guiadas por determinados pressupostos que ao negar o conflito correm o risco de encobrir a lógica nativa ${ }^{8}$.

Nesse sentido, as discussões advindas num primeiro momento dos livros de (ZALUAR, 1999) e (MISSE, 2006) parecem apontar para a necessidade de um constante escrutínio dos valores incrustados em nossa matriz disciplinar, cujos argumentos podem, como já mencionado, não escaparem da conhecida ideologia liberal iluminista, romântica e normatizadora ${ }^{9}$. Nesse sentido concordo com (SANTOS, 2005) quando esse diz que:

\footnotetext{
MISSE, M. Crime e violência no Brasil contemporâneo - estudos de Sociologia do crime e da violência urbana. Coleção conflitos, direitos e culturas. R.K. de Lima \& M. Misse (Coords.). Rio de Janeiro: Editora Lúmen júris, 2006.

${ }^{8}$ No texto "O uso e o abuso da Antropologia: reflexões sobre o feminismo e o entendimento intercultural" [Horizontes Antropológicos, 1(1)], Rosaldo (1995) fala sobre o problema da reprodução de uma tradição analítica etnocêntrica pela antropologia contemporânea.

9 "De acordo com a ideologia Liberal[...] os homens são iguais em capacidades e devem ser iguais em direitos. Contudo, para que essa liberdade não redunde em caos, todos devem ser solidários uns com os outros, sem renunciar a essa liberdade[...] segundo o Romantismo, cada um é diferente, mas sente saudade do tempo em que todos viviam comunitariamente e espera pelo retorno desse tempo[...], já os liberais apostam na utópica fraternidade[...] É na busca de reduzir os "inconvenientes" da liberdade, das diferenças singulares,etc. que se foi instalando e sendo aceito entre nós ocidentais e modernos um [...] sistema de domesticação dos indivíduos colocando em risco tanto as idéias liberais como as românticas[...] Esse sistema que envolve a elaboração e a aplicação de técnicas "científicas" de controle social será chamado de Regime Disciplinar” (FIGUEREDO, 2000; p. 44-6).
} 


\title{
HUMANAS
}

[...] Se fecharmos os olhos e os voltarmos a abrir, verificamos com surpresa que os grandes cientistas que estabeleceram e mapearam o campo teórico em que ainda hoje nos movemos viveram ou trabalharam entre o século XVIII e os primeiros vinte anos do século XX, de Adam Smith e Ricardo a Lavoisier e Darwin, de Marx e Durkheim a Max Weber e Pareto, de Humboldt e Planck a Poincaré e Einstein (SANTOS, 2005; p. 13-14).

Se aqueles pressupostos advindos de uma tradição durkheimiana do consenso e das sociologias marxistas e weberianas do conflito parecem não corresponder, em grande parte, às realidades brasileiras estudadas, a teoria simmeliana de conflito como constituinte de sociabilidade, por vezes uma sociabilidade violenta, deve ganhar força e sentido, se pensarmos nas relações como constituídas por uma forma que estrutura um grande número de interações diferentes, sejam elas de ciúme, guerra civil, competição econômica, acordo político, ou tráfico de drogas (VANDENBERGHE, 2005) ${ }^{10}$. Um depoimento retirado de meu diário escrito a partir de meu campo de doutorado que está sendo realizado em parte no presídio de Rio do Sul/SC, pode ser aqui elucidativo, vejamos:

\begin{abstract}
A gente vivia se esbofeteando, passar um dia sem brigar era um milagre, ele me deixava roxa, mas eu também não deixava por menos, também batia [...] até aqui na visita íntima a gente se estranha, um dia desses as meninas tiveram que separar a gente [...] o desgraçado teve a coragem de me dizer que de vez em quando dá uma "raladinha" com a vizinha, acho que se elas deixassem aquele dia eu tinha matado ele [...] pelo menos com as marcas das minhas unhas ele ficou $[. .$.$] assim a outra sabe de quem ele é [...] mas$ no fundo a gente se ama, e assim a gente vai vivendo [...] (Carla foi presa por tráfico de drogas).
\end{abstract}

Ou ainda, elejo mais um fragmento retirado de meu diário de campo do mestrado:

\footnotetext{
${ }^{10}$ Desde a década de 80 do século passado conforme (MORAES, 1983), principalmente na sociologia americana a discussão sobre conflito voltou a ordem do dia, não mais como fator negativo, mas com a idéia de positividade defendida por Simmel já no início do mesmo século. Nesse sentido, ao falar sobre o conflito em Simmel (VANDENBERGHE, 2005) professa que devemos conceber todas as diferenciações polares como uma só vida, devemos sentir o pulso de uma vitalidade central mesmo naquilo que, se considerado do ponto de vista de um ideal particular, não deveria existir absolutamente e é apenas algo negativo; devemos permitir que o sentido global de nossa existência brote de ambas as partes.
} 
Uma visita a Georg Simmel: o "conflito" como uma categoria crítica de análise conceitual ... Micheline Ramos de Oliveira

[...] um taxista trouxe uma pessoa até aqui perto da minha casa[...] aqui nos fundos [...] quando chegou aqui próximo a pessoa entrou num beco, fez com que o carro entrasse num beco sem saída [...] e essa pessoa, até era uma mulher [...] disse para ele: não grita, por aqui a barra é pesada [...] daí ele disse que na hora lembrou de mim, de uma outra vizinha, mas não fez nada pois ela estava armada, e ele disse que ela estava tão determinada a levar o dinheiro dele que para enfiar a faca nele não seria difícil [...] isso aconteceu quando eles começaram a vender droga aqui [...] e hoje em dia isso aqui é um absurdo, um absurdo mesmo [...] tem dias, acho que foi semana passada mesmo, eu estava lavando roupa[...] tinha duas policiais femininas aqui no beco, chegaram perto do portão [...] olharam para dentro do quintal [...] olharam para cá, para lá [...] né? de uma certa forma é desagradável, tu morar num lugar assim [...] é sempre bom ter uma pessoa cuidando, mas não por esse motivo [...] a gente não sabe quem é quem, se o policial veio comprar, veio dar alguma dica[...] eles estão sempre rondando[...] teve uma época que eles trouxeram um cachorro, dentro de tanta sujeira [...] o cachorro não farejou nada $[. .$.$] risos [...] tem cada caso que elas (trafican-$ tes) contam [...] elas não são nada discreta [...] digamos assim: se elas tiver conversando que compraram ou venderam droga ali no portão e me vêem ali, ou alguém, elas não falam mais baixo, continuam falando [...] estavam falando um dia desses que um dia a polícia bateu na casa de determinada pessoa, então essa pessoa encheu a boca de branca, aí quando o policial foi perguntar alguma coisa para ela, ela não podia nem falar, pois estava com a boca cheia de branca né? daí disse que o policial falou assim: agora tu não pode falar, tá com medo de falar [...] risos [...] não é porque ela tava com medo, mas sim porque tava com a boca cheia de branca [...] elas põe, escondem a branca dentro da calcinha, logo que tiram, já vendem na hora e vendem para alguém [...] tirar o montinho que eles fazem de branca [...] isso dá para ver [...] eles fazem ali no beco [...] isso a gente vê com tranqüilidade [...] é um montinho bem pequenininho[...] um pouco maior que uma cabeça de fósforo [...] enliadinho num plasticusinho, 


\title{
HUMANAS
}

\begin{abstract}
nesses plásticos de sacola de supermercado[...] se eles tem na mão e tu passas por eles, eles não escondem não, eles fazem questão de abrir a mão para tu vê o que eles tem na mão [...] um dia desses a polícia bateu na casa de uma guria, ela encheu a calça de petequinhas de branca, e depois a polícia foi embora, alguém veio comprar, ela tirou de dentro da calcinha, e vendeu [...] a pessoa levou aquilo mesmo [...] é bem por aí [...] assim a gente vai vivendo [...] convivendo com tudo isso [...] (Márcia, moradora do Matadouro).
\end{abstract}

Como podemos observar nas falas das informantes, mesmo causando algum sofrimento, o conflito aparece como constitutivo, se pensarmos nos domínios da cultura e da sociedade. Aqui, o tráfico de drogas, sem esquecer todos os infortúnios que tem causado à sociedade brasileira como um todo, desponta como emblemático para a reflexão de que se "[...] os diferentes mundos da cultura são realmente antagônicos entre si[...]", nesse caso entre moradores traficantes e moradores não- traficantes do Matadouro, “[...] os conflitos entre indivíduos e entre diferentes princípios formais são as precondições para uma determinada estrutura em sociedade", seja ela qual for, "[...] dando a sociedade textura, durabilidade e elasticidade" (LEVINE; in: SIMMEL, 2002; p. 44), seja onde for.

E é dialogando com a idéia de sociabilidades violentas (DIÓGENES, 1998), com a crítica a um entendimento das violências como um objeto moral (RIFIOTIS, 1997, 1998, 1999) e com a concepção de violências concebidas em sua positividade, ou seja, como constituintes de sociabilidades (GROSSI, 1991, 1995, 1998), (RIFIOTIS, 1997, 1998, 1999), que creio compartilhar com esses autores, da máxima simmeliana de que aquilo que num primeiro momento aparece como "desassociação", não passa de uma das formas elementares de sociabilidade, já que para o mestre o "verdadeiro" modelo da vida, "[...] en sentido absoluto, es uma lucha, que abarca la relativa oposición de lucha y paz[...]"(SIMMEL, 2002; p. 460).

Creio que as reflexões desenvolvidas pelos autores citados no parágrafo anterior podem servir como um ponto de partida para que atentemos que a antropologia não pode simplesmente parar no relativismo, mas tem que ir além e ter coragem de se perguntar se aquela forma de sociabilidade,- a princípio descartada por um problema moral (RIFIOTIS, 1997, 1998, 1999) que também constitui e é constituído por nossos pressupostos teórico- metodológicos-é uma forma que nós podemos pensar também, nessa lógica, refletir que deve ser possível modificar esquemas de pensamento de nossa filosofia a partir de nosso modo de reflexão. 
Eis aí o "perspectivismo simmeliano", que dando abertura à mobilidade dános a capacidade de explorar e de expor o objeto nas suas diversas facetas e nuances, "[...] sem que tudo isso convirja para uma apresentação acabada, conclusiva e final [...] Assim, o sujeito pode deslocar-se pela pluralidade dos caminhos possíveis, porque a mobilidade que permite isso é a mobilidade da própria vida" (WAIZBORT, 2000; p. 26-27). Ainda, esse comentário do mesmo autor sobre o pensamento simmeliano pode ser contundente para nossa reflexão:

O conceito de filosofia com que Simmel trabalha não está [...] ligado aos objetos da reflexão, mas sim ao modo dessa reflexão [...] primado do processo: aquela "atitude espiritual em relação ao mundo e à vida, uma forma e modo funcionais de apanhar as coisas e proceder mentalmente com elas" [...] Virando, rearranjando a constelação que trabalha, ele a mostra sob nova perspectiva, em variadas configurações. Assim, Simmel não somente é capaz de habilitar os mais díspares fragmentos do real como objeto da "profundidade metafísica" como, nesse processo, acerca-se desses objetos através de sua multideterminação, mostrando como a cada caminho percorrido, a cada perspectiva adotada, o objeto é acrescido de sentido [...] A pluralidade das perspectivas adotadas é um esforço em desvendar a pluralidade das possibilidades do objeto (WAIZBORT, 2000; p. 24-6).

Nesse viés, a pergunta descartianas de quem pensa, cede lugar primeiramente para a forma como se pensa e já que "[...] essa estética [...] estaria imbricada nos domínios da cultura, constituindo uma economia de forças para o pensamento" (MALDONADO, 1998; p. 175-76), o "como" vai ser composto pela soma da lógica do nativo e da epistemologia, matriz disciplinar e estética do antropólogo.

Assim, pensa-se que a idéia de que as regras, convenções e valores constituintes do "recurso estilístico" utilizado pelo antropólogo na obra etnográfica, está indubitavelmente grudado a um contexto sócio-histórico-cultural dado, e definido, além de outros, pelas linhagens acadêmicas, menos ou mais flexíveis, seguidas por cada autor.

Nesse sentido, o "perspectivismo simmeliano" pode se tornar crucial para os estudos antropológicos das violências por propiciar a reflexão do antropólogo sobre si, sobre a forma como produz e sobre sua produção, sustentada por valores estéticos e éticos, altamente vinculados as suas adesões teórico-conceituais e políticas, construídas coletivamente. 
Enfim, considerando que "todas as formas sociais aparecem sob nova luz quando vistas pelo ângulo do caráter sociologicamente positivo do conflito" (SIMMEL, 1983; p. 124) chegamos ao fim de nossa visita a Georg Simmel, desejando que ela seja cada vez menos esporádica e mais freqüente em nossos estudos antropológicos de violências no Brasil contemporâneo, no sentido de dar-nos subsídios importantes para a compreensão de um fenômeno que pela sua complexidade roga por categorias de análises, como a de conflito simmeliano discutida nesse artigo, que tem como pressuposto ao invés de fechar, abrir a cada olhar do pesquisador novas perspectivas de análise, novas facetas do objeto.

\section{Referências bibliográficas}

BUTLER, J. Problemas de gênero: feminismo e subversão da identidade. Rio de Janeiro: Civilização Brasileira, 2003.

BUTLER, J. Imitation and Gender Insubordination. In: D. Fuss (Org.). Lesbian theories, gay theories. Nova York e Londres: Routledge, 1991.

CALDEIRA, T. Cidade de muros. Crime, segregação e cidadania em São Paulo. São Paulo: Editora 34 e Edusp, 2000.

CERTEAU, M. de. A invenção do cotidiano:1. Artes de fazer. Petrópolis: Editora Vozes, 1995.

DELEUZE, G. \& Guattari, F. Mil Platôs. Capitalismo e esquizofrenia. Vol.1. Tradução Aurélio G. Neto e Célia P. Costa. São Paulo: Editora 34, 2004.

DIÓGENES, G. Cartografias da cultura e da violência: gangues, galeras e o movimento Hip-Hop. São Paulo: Annablume, 1998.

ECKERT, C. \& ROCHA, A.L.C. da. Imagens do tempo nos meandros da memória: por uma etnografia da duração. Porto Alegre: Banco de Imagens e Efeitos Visuais, PPGAS/UFRGS, 2000.

ECKERT, C. \& ROCHA, A.L.C. da. A memória como espaço fantástico. Porto Alegre: Banco de Imagens e Efeitos Visuais, PPGAS/UFRGS, 2000.

ECKERT, C. \& ROCHA, A.L.C. da. Premissas para o estudo da memória coletiva no mundo urbano contemporâneo sob a ótica dos itinerários urbanos e suas formas de sociabilidade. Porto Alegre: Banco de Imagens e Efeitos Visuais, PPGAS/UFRGS, 2000.

ECKERT, C. \& ROCHA, A.L.C. da. Jogos de memória. Porto Alegre: Banco de Imagens e Efeitos Visuais, PPGAS/UFRGS, 2000. 
Uma visita a Georg Simmel: o "conflito" como uma categoria crítica de análise conceitual ... Micheline Ramos de Oliveira

ROCHA, A.L.C. da. Meio ambiente e direitos humanos: conflitos e dilemas da contemporaneidade. In: C. Fonseca e colaboradores (Orgs.). Antropologia, diversidade e direitos humanos: diálogos interdisciplinares. Porto Alegre: UFRGS Editora, 2004.

FOUCAULT, M. Microfisisica do poder. Rio de Janeiro: Edições Graal, 1972a.

FOUCAULT, M. A arqueologia do saber. Petrópolis: Vozes e Lisboa: Centro do Livro Brasileiro, $1972 \mathrm{~b}$.

GEERTZ, C. A Interpretação das culturas. Rio de Janeiro: Zahar, 1978.

GROSSI, M.P. Vítimas ou cúmplices? Dos diferentes caminhos da produção acadêmica sobre violência contra a mulher no Brasil. Caxambu: XV Encontro Anual da AMPOCS (15-18 de outubro), 1991.

GROSSI, M.P. Novas/velhas violências contra as mulheres no Brasil. Revista Estudos Feministas, 4(1): Florianópolis, 1995.

GROSSI, M.P. Rimando amor com dor: reflexões sobre violência no vínculo afetivo- conjugal. In: M.P. GROSSI \& J.M. PEDRO. Masculino, Feminino, Plural. Florianópolis: Editora Mulheres, 1998.

MALINOWSKI, B. Os argonautas do pacífico ocidental. São Paulo: Abril Cultural. Vol. XLII (coleção Os Pensadores), 1976.

MOORE, H. Fantasias de poder e fantasias de identidade:gênero, raça e violência. Cadernos Pagu, 14: 13-44, 2000.

MORAES, E. (Org.). Simmel: Sociologia. São Paulo: Editora Ática, 1983.

OLIVEIRA, M.R. Se correr o bicho pega, se ficar o bicho come: estudos antropológico de trajetórias sociais e itinerários urbanos sob o prisma da cultura do medo entre mulheres/mães moradoras do Bairro "Matadouro", Itajaí/SC. Dissertaçao de mestrado, PPG Antropologia Social, UFSC, 2002.

RIFIOTIS, T. Violência em plural y el lenguaje de las diferencias. Revista Mosaico, Buenos Aires, 1999a.

RIFIOTIS, T. Les médias et les violences: points de repères sur lá réception. École de Criminologie, Université de Montreal, 1999b.

RIFIOTIS, T. A mídia, o leitor modelo e a denúncia da violência policial: o caso favela Naval (Diadema). Revista São Paulo em Perspectiva, 13(4): 28-41, 1997. 
RIFIOTIS, T.; DIAS, L. \& ZENAIDE, M.N.T. Páginas policiais na imprensa paraibana. Entrevista com repórteres e editores sobre violência e ação policial. Signo - Revista de Comunicação, IV (Dezembro, 1998.

SANTOS, B. de S. Um discurso sobre as ciências. São Paulo: Cortez, 2005.

ROSALDO, M. O uso e o abuso da antropologia: reflexões sobre o feminismo e o entendimento intercultural. Horizontes Antropológicos, 1(1): 11-36, 1995.

SCOTT, J. Igualdade versus diferença: os usos da teoria pós-estruturalista. Debate Feminista. Cidadania e feminismo, 1999.

SIMMEL, G. A natureza sociológica do conflito. In: E. Morais (Org.). Simmel: sociologia. São Paulo: Editora Ática, 1983.

SIMMEL, G. Estética e sociologia. Tradução S.C. Maldonado. Política e Trabalho (14 de setembro): PPGS/UFPB, 1998.

SIMMEL, G. Sobre a individualidade e as formas sociais. Quilmes: Universidad Nacional de Quilmes, 2002.

SIMMEL, G. A metrópole e a vida mental. In: O.G. VELHO. O fenômeno urbano. Rio de Janeiro: Zahar, 1967.

VANDENBERGHE, F. As sociologias de Georg Simmel. Tradução de M.R.F. Peres. Bauru: Edusc e Belém: EDUFPA, 2005.

WAIZBORT, L. As aventuras de Georg Simmel. São Paulo: Editora 34, 2000.

WOLF, E. Antropologia e poder. In: B. Feldman-Bianco e G.L. Ribeiro (Orgs.). Brasília: Editora Universidade de Brasília, 2003.

ZALUAR, A. Violência e Crime. O que ler na Ciência Social brasileira. Antropologia (1970-1995). São Paulo e Brasília: Editora Sumaré e CAPES, 1999. 